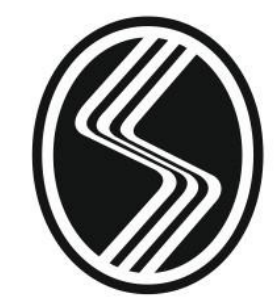

SAKARYA ÜNIVERSITESİ

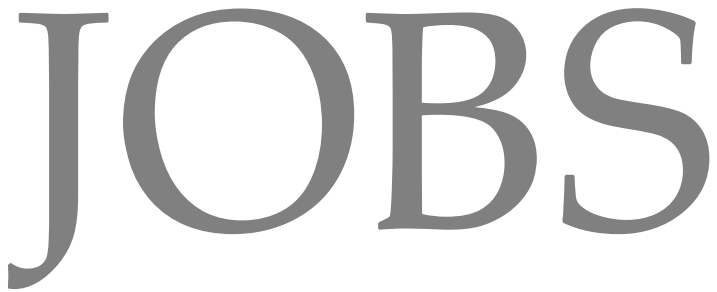

İşletme Bilimi Dergisi

The Journal of Business Science

Sakarya Üniversitesi / Sakarya University

İşletme Fakültesi / Faculty of Business

$\begin{array}{ll}\text { Cilt/Volume } & : 5 \\ \text { Say1/Issue } & : 3 \\ \text { Yil/Year } & : 2017\end{array}$

ISSN:2148-0737 


\section{İNDEXLER}

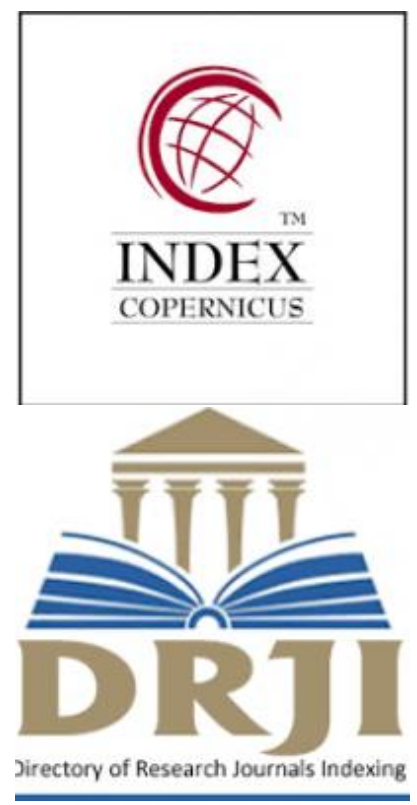

\section{Google}

ii
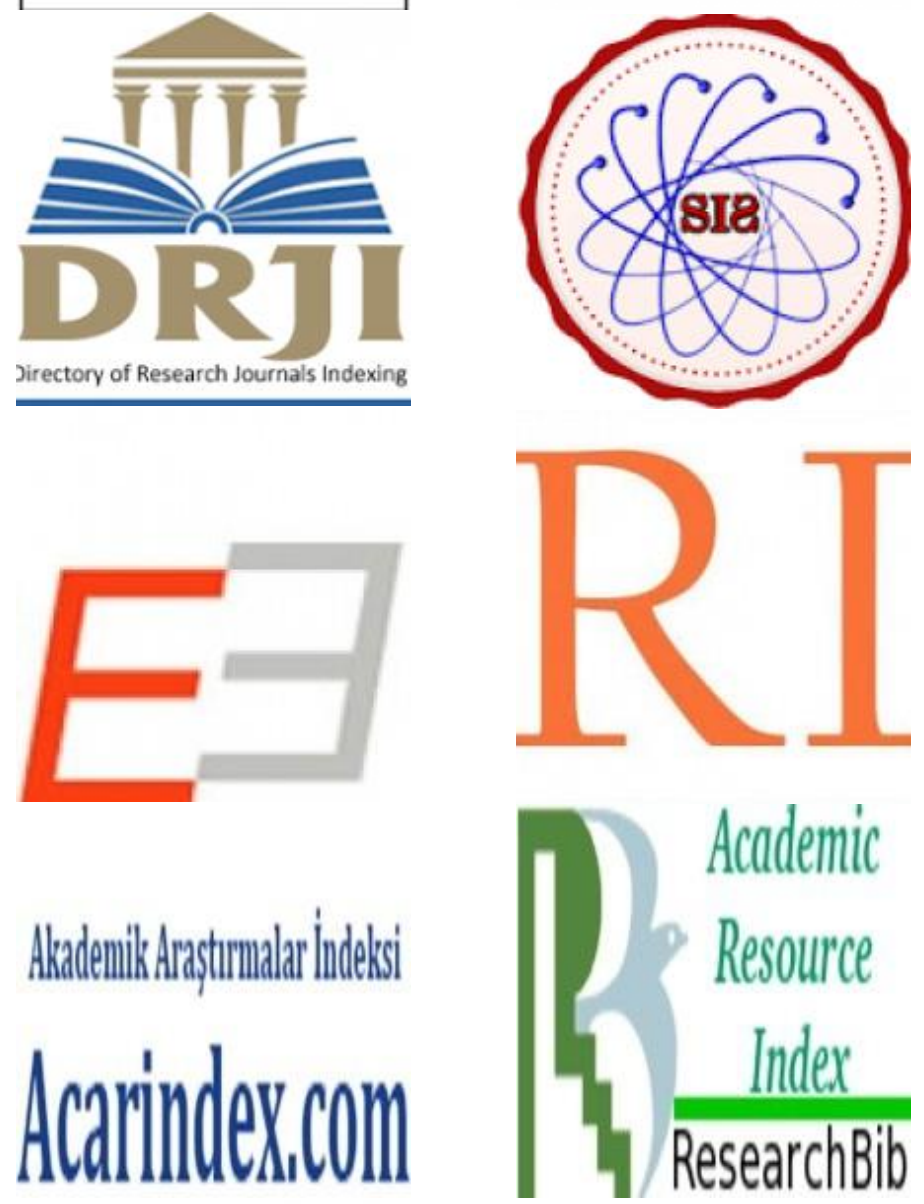
Prof.Dr. Gültekin YILDIZ

Imtiyaz Sahibi / Owner

Prof.Dr. Kadir ARDIÇ

Editör / Editor

Doç. Dr. Mahmut AKBOLAT

Editör Yardımcısı / Assoc. Editor

Doç.Dr. Mustafa Cahit ÜNĞAN

Doç. Dr. Hakan TUNAHAN

Danışma Kurulu/Advisory Board

Prof. Dr. Ahmet Vecdi CAN

Prof. Dr. Bülent SEZEN

Prof. Dr. Dilaver TENGİLIMOĞLU

Prof. Dr. Erman COŞKUN

Prof. Dr. Kadir ARDIÇ

Prof. Dr. Mehmet BARCA

Prof. Dr. Nihat ERDOĞMUŞ

Prof. Dr. Orhan BATMAN

Prof. Dr. Recai COŞKUN

Prof. Dr. Remzi ALTUNIŞIK

Prof. Dr. Selahattin KARABINAR

Prof. Dr. Sidika KAYA

Prof. Dr. Şevki ÖZGENER

Prof. Dr. Türker BAŞ

Doç.Dr. Surendranath Rakesh JORY
Sakarya Üniversitesi

Gebze Yüksek Teknoloji Enstitüsü

Atılım Üniversitesi

Sakarya Üniversitesi

Sakarya Üniversitesi

Ankara Sosyal Bilimler Üniversitesi

İstanbul Şehir Üniversitesi

Sakarya Üniversitesi

Sakarya Üniversitesi

Sakarya Üniversitesi

İstanbul Üniversitesi

Hacettepe Üniversitesi

Nevşehir Üniversitesi

Sakarya Üniversitesi

Southampton Üniversitesi 
Işletme Bilimi Dergisi
Yayın Kurulu / Editorial Board

Prof.Dr. Kadir ARDIÇ

Doç. Dr. Mahmut AKBOLAT

Doç.Dr. Mustafa Cahid ÜNĞAN

Doç. Dr. Hakan TUNAHAN

Sekreterya / Secreteria

Arş. Gör. Özgün ÜNAL

Arş. Gör. Gülcan KAHRAMAN

Arş. Gör. Mustafa AMARAT

Arş. Gör. Ayhan DURMUŞ

İşletme Bilimi Dergisi'nde yer alan makalelerin bilimsel sorumluluğu yazara aittir. Yayınlanmış eserlerden kaynak gösterilmek suretiyle alıntı yapılabilir.

Scientific responsibility for the articles belongs to the authors themselves. Published articles could becited in other publications provided that full reference is given.

İşletme Bilimi Dergisi; www.dergipark.gov.tr/jobs Sakarya Üniversitesi İşletme Fakültesi Dekanlığı jobs@sakarya.edu.tr Esentepe Kampüsü 54187 Serdivan/SAKARYA 


\section{Dergi Hakemleri/ References}

Prof. Dr. A. Vecdi Can

Prof. Dr. Adem Öğüt

Prof. Dr. Ahmet Bardakç1

Prof. Dr. Aykut Hamit Turan

Prof. Dr. Ayşe İrmiş

Prof. Dr. Bayram Şahin

Prof. Dr. Bayram Zafer Erdoğan

Prof. Dr. Dilaver Tengilimoğlu

Prof. Dr. Durmuş Acar

Prof. Dr. Ekrem Tatoğlu

Prof. Dr. Erman Coşkun

Prof. Dr. Fatih Ertaş

Prof. Dr. Gülten Gümüştekin

Prof. Dr. Halit Keskin

Prof. Dr. Hasan Tutar

Prof. Dr. Haydar Sur

Prof. Dr. İsmet Şahin

Prof. Dr. Kadir Ardıç

Prof. Dr. Kıymet Çalıyurt

Prof. Dr. Mehmet Akif Çukurçayır

Prof. Dr. Mehmet Barca

Prof. Dr. Mehmet Sarışık

Prof. Dr. Mehmet Selami Yıldiz

Prof. Dr. Muhsin Halis

Prof. Dr. Musa Özata

Prof. Dr. Nazan Günay

Prof. Dr. Nejat Bozkurt

Prof. Dr. Nuran Cömert

Prof. Dr. Orhan Batman

Prof. Dr. Ömer Torlak

Prof. Dr. Recai Coşkun

Prof. Dr. Recep Pekdemir

Prof. Dr. Remzi Altunışık

Prof. Dr. Selahattin Karabınar

Prof. Dr. Selman Aziz Erdem

Prof. Dr. Serap Benligiray

Prof. Dr. Serdar Özkan

Prof. Dr. Şakir Sakarya

Prof. Dr. Şevki Özgener

Prof. Dr. Suayyip Calış

Prof. Dr. Sıdıka Kaya

Prof. Dr. Sima Nart

Prof. Dr. Şuayip Özdemir

Prof. Dr. Türker Baş

Prof. Dr. Ümit Gücenme Gençoğlu

Prof. Dr. Vasfi Haftac1

Prof. Dr. Yıldız Özerhan

Prof. Dr. Yusuf Çelik
Sakarya Üniversitesi

Selçuk Üniversitesi

Pamukkale Üniversitesi

Sakarya Üniversitesi

Pamukkale Üniversitesi

Hacettepe Üniversitesi

Anadolu Üniversitesi

Gazi Üniversitesi

Süleyman Demirel Üniversitesi

Bahçeşehir Üniversitesi

Sakarya Üniversitesi

Gaziosmanpaşa Üniversitesi

Dumlupınar Üniversitesi

Gebze Yüksek Teknoloji Enstitüsü

Sakarya Üniversitesi

İstanbul Üniversitesi

Hacettepe Üniversitesi

Sakarya Üniversitesi

Trakya Üniversitesi

Selçuk Üniversitesi

Yıldırım Beyazıt Üniversitesi

Sakarya Üniversitesi

Düzce Üniversitesi

Kocaeli Üniversitesi

Ahi Evran Üniversitesi

Ege Üniversitesi

Marmara Üniversitesi

Marmara Üniversitesi

Sakarya Üniversitesi

Karatay Üniversitesi

Sakarya Üniversitesi

İstanbul Üniversitesi

Sakarya Üniversitesi

İstanbul Üniversitesi

Kocaeli Üniversitesi

Anadolu Üniversitesi

İzmir Ekonomi Üniversitesi

Balıkesir Üniversitesi

Nevşehir Üniversitesi

Sakarya Üniversitesi

Hacettepe Üniversitesi

Sakarya Üniversitesi

Afyon Kocatepe Üniversitesi

Sakarya Üniversitesi

Uludağ Üniversitesi

Kocaeli Üniversitesi

Gazi Üniversitesi

Hacettepe Üniversitesi
İsletme Bilimi Dergisi

Cilt:5 Sayı:3 2017 
İsletme Bilimi Dergisi

Cilt:5 Sayı:3 2017
Doç. Dr. Abdurrahman benli

Doç. Dr. Adem Sağır

Doç. Dr. Aşkın Özdağoğlu

Doç. Dr. Aykut Hamit Turan

Doç. Dr. Bayram Topal

Doç. Dr. Bora Yenihan

Doç. Dr. Buket Bora Semiz

Doç. Dr. Burcu Candan

Doç. Dr. Burhanettin Zengin

Doç. Dr. Buket Bora Semiz

Doç. Dr. Cemal Sezer

Doç. Dr. Cemal İyem

Doç. Dr. Ece Armağan

Doç. Dr. Engin Dinç

Doç. Dr. Erdoğan Kaygın

Doç. Dr. Erkan Erdemir

Doç. Dr. Faruk Anıl Konuk

Doç. Dr. Ferudun Kaya

Doç. Dr. Fikret Çankaya

Doç. Dr. Fuat Man

Doç. Dr. Gülfen Tuna

Doç. Dr. Hakan Tunahan

Doç. Dr. Haluk Bengü

Doç. Dr. Hasan Ayyıldız

Doç. Dr. Hasan Latif

Doç. Dr. Hayrettin Zengin

Doç. Dr. Kazım Ozan Özer

Doç. Dr. Kemal Can Kılıç

Doç. Dr. Kurtuluş Kaymaz

Doç. Dr. Mahmut Akbolat

Doç. Dr. Mahmut Hızıroğlu

Doç. Dr. Mehmet Saraç

Doç. Dr. Mesut Çimen

Doç. Dr. Muammer Mesci

Doç. Dr. Musa Said Döven

Doç. Dr. Mustafa Cahid Ünğan

Doç. Dr. Mustafa Kemal Demirci

Doç. Dr. Mutlu Başaran Öztürk

Doç. Dr. Müjdat Özmen

Doç. Dr. Nevran Karaca

Doç. Dr. Nihal Sütütemiz

Doç. Dr. Nilgün Sarıkaya

Doç. Dr. Oğuz Işık

Doç. Dr. Oğuz Türkay

Doç. Dr. Özgür Uğurluoğlu

Doç. Dr. Ramazan Aksoy

Doç. Dr. Seçil Taştan

Doç. Dr. Sedat Bostan

Doç. Dr. Selami Özcan
Sakarya Üniversitesi

Karabük Üniversitesi

Dokuz Eylül Üniversitesi

Sakarya Üniversitesi

Sakarya Üniversitesi

Kırklareli Üniversitesi

Bilecik Şeyh Edebali Üniversitesi

Kocaeli Üniversitesi

Sakarya Üniversitesi

Bilecik Şeyh Edebali Üniversitesi

Sakarya Üniversitesi

Sakarya Üniversitesi

Adnan Menderes Üniversitesi

Karadeniz Teknik Üniversitesi

Kafkas Üniversitesi

İstanbul Şehir Üniversitesi

Sakarya Üniversitesi

Abant İzzet Baysal Üniversitesi

Karadeniz Teknik Üniversitesi

Sakarya Üniversitesi

Sakarya Üniversitesi

Sakarya Üniversitesi

Niğde Üniversitesi

Karadeniz Teknik Üniversitesi

Sakarya Üniversitesi

Sakarya Üniversitesi

Nişantaşı Üniversitesi

Çukurova Üniversitesi

Uludağ Üniversitesi

Sakarya Üniversitesi

Ankara Sosyal Bilimler Üniversitesi

İstanbul Üniversitesi

Acıbadem Üniversitesi

Düzce Üniversitesi

Osmangazi Üniversitesi

Sakarya Üniversitesi

Dumlupınar Üniversitesi

Niğde Üniversitesi

Osmangazi Üniversitesi

Sakarya Üniversitesi

Sakarya Üniversitesi

Sakarya Üniversitesi

Hacettepe Üniversitesi

Sakarya Üniversitesi

Hacettepe Üniversitesi

Bülent Ecevit Üniversitesi

Marmara Üniversitesi

Gümüşhane Üniversitesi

Yalova Üniversitesi 
Doç. Dr. Senay Yürür

Doç.Dr. Şevki Ulama

Doç. Dr. Tuncay Yılmaz

Doç. Dr. Yasemin Özdemir

Doç. Dr. Yasin Şehitoğlu

Doç Dr. Yunus Emre Öztürk

Yrd. Doç. Dr. A. Mohammed Abubakar

Yrd. Doç. Dr. Adem Akbıyık

Yrd. Doç. Dr. Ahmet Yağmur Ersoy

Yrd. Doç. Dr. Ali Coşkun

Yrd. Doç. Dr. Algın Okursoy

Yrd. Doç. Dr. Ayhan Serhateri

Yrd. Doç. Dr. Ceren Giderler Atalay

Yrd. Doç. Dr. Derya Ergun Özler

Yrd. Doç. Dr. Dilek Özceylan

Yrd. Doç. Dr. Esra Dil

Yrd. Doç. Dr. Fatma Gamze Bozkurt

Yrd. Doç. Dr. Filiz Konuk

Yrd. Doç. Dr. Halil İbrahim Cebeci

Yrd. Doç. Dr. Hakan Murat Arslanhan

Yrd. Doç. Dr. Harun Kırılmaz

Yrd. Doç. Dr. İrfan Usta

Yrd. Doç. Dr. İsa Demirkol

Yrd. Doç. Dr. Mihriban Cindiloğlu

Yrd. Doç. Dr. Murat Ayanoğlu

Yrd. Doç. Dr. Mustafa Kenan Erkan

Yrd. Doç. Dr. Mustafa Yıldırım

Yrd. Doç. Dr. Nermin Akyel

Yrd. Doç. Dr. Nesrin Akca

Yrd. Doç. Dr. Onur Dirlik

Yrd. Doç. Dr. Orhan Kandemir

Yrd. Doç. Dr. Özlem Balaban

Yrd. Doç. Dr. Recep Yılmaz

Yrd. Doç. Dr. Safiye Sencer

Yrd. Doç. Dr. Sedat Durmuşkaya

Yrd. Doç. Dr. Sema Polatçı

Yrd. Doç. Dr. Sema Yiğit

Yrd. Doç. Dr. Sema Ülkü

Yrd. Doç. Dr. Sinan Esen

Yrd. Doç. Dr. Sümeyra A. Danışman

Yrd. Doç. Dr. Şevki Ulama

Yrd. Doç. Dr. Şuayyip Doğuş Demirci

Yrd. Doç. Dr. Şule Yıldız

Yrd. Doç. Dr. Tarık Semiz

Yrd. Doç. Dr. Tuncay Turaboğlu

Yrd. Doç. Dr. Umut Sanem Çiftçi

Öğr. Gör. Dr. Hüseyin İskender

Öğr. Gör. Dr. İlker Calayoğlu

Arş. Gör. Dr. Emrah Özsoy
Yalova Üniversitesi

Sakarya Üniversitesi

Sakarya Üniversitesi

Sakarya Üniversitesi

Yıldız Teknik Üniversitesi

Selçuk Üniversitesi

Aksaray Üniversitesi

Sakarya Üniversitesi

Sakarya Üniversitesi

Boğaziçi Üniversitesi

Adnan Menderes Üniversitesi

Sakarya Üniversitesi

Dumlupınar Üniversitesi

Dumlupınar Üniversitesi

Sakarya Üniversitesi

Sakarya Üniversitesi

Sakarya Üniversitesi

Sakarya Üniversitesi

Sakarya Üniversitesi

Düzce Üniversitesi

Sakarya Üniversitesi

Gaziosmanpaşa Üniversitesi

Kırıkkale Üniversitesi

Hitit Üniversitesi

Sakarya Üniversitesi

Sakarya Üniversitesi

Sakarya Üniversitesi

Sakarya Üniversitesi

Kırıkkale Üniversitesi

Osmangazi Üniversitesi

Kastamonu Üniversitesi

Sakarya Üniversitesi

Sakarya Üniversitesi

Sakarya Üniversitesi

Sakarya Üniversitesi

Gaziosmanpaşa Üniversitesi

Ordu Üniversitesi

Sakarya Üniversitesi

Sakarya Üniversitesi

Mevlana Üniversitesi

Sakarya Üniversitesi

İzmir Kâtip Çelebi Üniversitesi

Sakarya Üniversitesi

Bilecik Şeyh Edebali Üniversitesi

Mersin Üniversitesi

Sakarya Üniversitesi

Sakarya Üniversitesi

Okan Üniversitesi

Sakarya Üniversitesi
İşletme Bilimi Dergisi

Cilt:5 Sayı:3 2017 


\section{Değerli Bilim İnsanları,}

İşletme Bilimi Dergisi, sizlerin ilgisi ve desteği ile her sayıda daha da güçlenerek 2017 yılından itibaren yılda 3 sayı çıkarmaya başlamıştır. Bu kapsamda 2017 yılı 3. Sayısı olan Aralık Sayımızla huzurlarınızdayız. Bu sayıda biri toplam 12 makalemiz bulunmaktadır. Dergimizin diğer sayılarında olduğu gibi, bu sayısında da üretim yönetimi, örgütsel davranış, yönetim bilimi, yönetim bilişim sistemleri, uluslararası ticaret gibi farklı alanlardan ve ağırlıklı olarak ampirik çalışmalar yer almaktadır. Dergi politikası olarak bundan sonraki sayılarımızda da işletme bilimine dayalı farklı disiplinlerden gelen çalışmaları yayınlamaya özen göstereceğiz.

Dergimizin bu sayısının çımmasında da emeklerini esirgemeyen ekip arkadaşlarım ve siz değerli bilim insanlarına katkılarından dolayı şükranlarımı sunar; dergimizin okurlarımız ve bilim insanlarına faydalı olması dikeklerimle sonraki sayılarımızda işletmeciliğin güncel çalışmalarını bilim dünyasının hizmetine sunmak için siz değerli bilim insanları ve araştırmacıların katkılarını bekleriz.

Saygılarımızla...

Doç. Dr. Mahmut AKBOLAT

Editör 


\section{İÇINNDEKİLER}

Cilt 5 Sayı 3

Araştırma Makaleleri

DENIM PANTOLONU ÜRETIMINDE DEĞER AKIŞ HARITALANDIRMA YÖNTEMININ UYGULAMASI

Sibel ESER, Prof. Dr. Mehmet Selami YILDIZ

MOBIL BANKACILIK UYGULAMALARININ BENIMSENMESINE YÖNELIK DAVRANIŞSAL NIYETLERI ETKILLEYEN FAKTÖRLER ÜZERINE BİR 25-59 ARAŞTIRMA

Kadir KURT, Yrd. Prof. Dr. Aykut Hamit TURAN

TOPLAM VERIMLI BAKIM UYGULAYAN BİR ISSLETMEDE BAKIM PERSONELININ PERFORMANS DEĞERLEME PUANLARININ ENTROPI 59-78 TABANLI VIKOR SIRALAMASI İLE KARŞILAŞTIRILMASI

Arş. Gör. Dr. Emre Bilgin Sarı

FINANSAL OKURYAZARLIK: HANEHALKI ÜZERINE BİR ARAŞTIRMA 79-104 Öğr. Gör. Emine GÜLER, Doç.Dr. Hakan TUNAHAN

5018 SAYILI KANUN KAPSAMINDA KAMU KURUMLARINDA İç KONTROL SİSTEMI: MALIYYE BAKANLIĞI UYGULAMASININ 105-125 İNCELENMESI

Yılmaz ÇALIŞKAN, Doç.Dr. Yavuz ÇiFTCI

ŞEHİR IÇĊ TOPLU TAŞIMA HATLARININ HIZZMET ETKINLIIĞININ VERI ZARFLAMA ANALIZII İLE ÖLÇÜLMESİ: ÖZEL VE KAMU IŞSETMELERININ KARŞILAŞTIRILMASI

Yrd. Doç. Dr. Samet GÜNER, Yrd. Doç. Dr. Kamil TAŞKIN,

Öğr. Gör. Gökhan GÜRLER

ÇEVIK ÜRETIM TARZI FAALIYYET GÖSTEREN GELENEKSEL TÜRK EL SANATLARI ISSLETMELERININ CANLANDIRILMASI ÇALIŞMALARININ 147-172 BULANIK TOPSIS YÖNTEMI İLE DEĞERLENDIRILILMESI

Yrd. Doç. Dr. Hakan Murat ARSLAN, Doç. Dr. Selami ÖZCAN

GENETIK ALGORTIMA İLE PORTFÖY SEÇIMINDE KRİZ DÖNEMI ETKİSİ, BISTT-30'DA BİR UYGULAMA 
Işletme Bilimi Dergisi Cilt:5 Sayı:3 2017
THE RELATIONSHIP BETWEEN BASIC CHARACTERISTICS OF LEARNING ORGANIZATIONS AND FINANCIAL PERFORMANCE

Yrd. Doç. Dr. Yunus Emre TAŞGiT, Gül Büşra ÖZDAMAR,

Yrd. Doç. Dr. Faruk Kerem ŞENTÜRK

DIŞARIDAN İŞ SAĞLIĞI VE GÜVENLİĞI HIZZMETİ SAĞLAMA MODELLERINDEN Bİİ OLARAK TÜRKIYY'DE UYGULANAN ORTAK SAĞLIK GÜVENLIK BİRIMİ HIZZMETLERININ ETKINLIĞİ: ÖRNEK BïR 207-234 UYGULAMA

Yrd. Doç. Dr. Serdar ORHAN, Elifnaz ÖZKAN, Sezgin UYSAL

SINEMA FILMLERINDEKI MUHASEBECI KARAKTERLERININ KİŞILIK ÖZELLIKKLERI: HOLLYWOOD FILMLERI İNCELEMESI

Şeyda ALANKAYA, Yrd. Doç. Dr. Sema AKPINAR

TESTING MCLOUGHLIN'S TRUST MODEL ON TURKISH INFORMATION TECHNOLOGY EMPLOYEES

Arş. Gör. Dr. Emrah ÖZSOY, Dr. Dominic McLOUGHLIN, 


\title{
TESTING McLOUGHLIN'S TRUST MODEL ON TURKISH INFORMATION TECHNOLOGY EMPLOYEES ${ }^{1}$
}

\author{
Arş. Gör. Dr. Emrah ÖZSOY \\ Sakarya University, Sakarya Business School, Deprtment of Business \\ eozsoy@sakarya.edu.tr \\ ORCID ID: orcid.org/0000-0003-2886-8824 \\ Dr. Dominic McLOUGHLIN \\ Western Sidney University \\ dom.mcl@gmail.com \\ ORCID ID: orcid.org/0000-0002-0106-4423 \\ Arş. Gör. Dr. Osman USLU \\ Sakarya University, Sakarya Business School, Deprtment of Business \\ ouslu@sakarya.edu.tr \\ ORCID ID: orcid.org/0000-0002-0571-6281
}

\begin{abstract}
Aim: The purpose of this study is to replicate McLoughlin's (2014) Trust Model developed on the sample of knowledge workers in Australia. McLoughlin' (2014) Trust Model includes variables such as trust reliance, trust disclosure, trust in organisation, change, perceived character of supervisors, communication, participation, organizational citizenship behaviour, job satisfaction, support for change direction, and affective commitment.

Method: In this study all the variables were measured with the scales that were used in McLoughlin' (2014) study on IT employees sample. 121 IT employees participated in this research from several organizations in Turkey.

Findings: All the scales were found to be valid and reliable. Trust in supervisor, communication and trust in senior management effected positively to employees' attitudes towards work and organization.

Results: The results indicated that the Turkish Model is consistent with the Australian Model expect for minor differences.

Key words: Trust, Organizational Trust, IT Employees.

\footnotetext{
${ }^{1}$ This research is part of an international research project which aims to compare three different countries (i.e., Australia, Turkey, and Ukraine) in terms of trust in the workplace for IT employees.
} 
Testing McLoughlin's Trust Model

\section{MCLOUGHLIN'IN GÜVEN MODELININN TÜRK BİLGI TEKNOLOJİLERİ ÇALIŞANLARI ÜZERINDE TEST EDİLMESİ}

\section{ÖZ}

Amaç: Bu çalışmanın amacı McLoughlin'ın (2014) Avusturalya'da bilgi çalışanları örneklemi üzerinde geliştirdiği modelin test edilmesidir. McLoughlin'ın (2014) modeli, iletişim güvenliği, güvenin ortaya çıkması, örgüte güven, değişim, yöneticilerin algılanan karakteri, iletişim, katılım, örgütsel vatandaşlık davranışı, iş tatmini, değişim yönüne verilen destek ve duygusal bağlllık gibi değişkenleri içermektedir.

Yöntem: Çalışmada tüm değişkenler McLoughlin'ın (2014) IT çalışanları örnekleminde yürütülen çalışmasında kullanılan ölçeklerle ölçülmüştür. Araştırmada Türkiye'de çeşitli sektörlerde faaliyet gösteren 121 IT çalışanı katılmıştır.

Bulgular: Tüm ölçeklerin geçerli ve güvenilir olduğu tespit edilmiştir. Yöneticiye güven, iletişim ve yönetime güven çalışanların işe ve örgüte yönelik tutumlarını pozitif etkilemiştir.

Sonuç: Araştırma bulgularına göre küçük farklılıklar dışında Türk Modeli ve Avusturalya Modeli birbirleri ile uyumludur.

Anahtar Kelimeler: Güven, Örgütsel Güven, IT Çalışanları

\section{I.INTRODUCTION}

In the management literature, trust is considered as a vital issue for organizational success (Meyerson et al., 2006). Trust in organizations has been associated with many critical variables such as profitability (Davis et al., 2000), team success (Webber, 2002), organizational health (Beccerra and Gupta, 1999). Therefore research highlighted the importance of trust for organizations. As trust is a broad concept, it is examined at different levels in organizations such as trust in supervisor, trust in co-workers, and trust in organizations (Börü et al., 2007:50: Özen, 2003:187). Thus it is necessary to examine trust concept in terms of different levels and variables so that its role for organizations could be better understood. There are many different approaches to trust concept and thus there is no certain definition of trust that is accepted by all researchers. Moorman et al., (1993) define trust concept as "a willingness to rely on an exchange partner in whom one has confidence". Shaw (1997) defines trust as one's belief that another will meet his/her positive expectations. Rousseau (1998) defines trust as "trust is a psychological state comprising the intention to accept vulnerability based 
upon positive expectations of the intentions or behavior of another. In general it can stated that trust is a psychological phenomenon (Costa et al., 2001) which includes risk (Lewicki and Bunker, 1996). Trust has various benefits for both organizations and employees. As Straiter (2005) states trust based relationships between subordinates and employees effect organizational performance, job satisfaction and organizational commitment. So it seems to be crucial to develop trustworthy relations in organizations. On the other hand it is also important to investigate antecedents and outcomes of trust. Considering Turkish literature little is known regarding trust in knowledge workers and IT Organizations. As we are in a highly intensive knowledge age, Information technology (IT) organizations should be considered specifically in terms of trust. McLoughlin (2014) examined the interrelationships among critical variables such as, trust in organisation, change, perceived character of supervisor, communication, organizational citizenship behaviour, job satisfaction, support for change direction, and affective commitment. Although trust in organizational context has been studied in terms of critical variables, such as job satisfaction, commitment, personality, McLoughlin's (2014) research integrated some critical variables and proposed a comprehensive model for IT employees. However, it is still unknown whether his model could be applicable in cross-cultural settings. Therefore we conducted the current study in order to test this model in Turkey sample. By this research we aimed to contribute to the trust literature by focusing on IT organizations in which change and communication are pivotal. In figure 1, McLoughlin's (2014) initial statistical model was exhibited.

\section{Testing \\ McLoughlin's \\ Trust Model}

259 


\section{Testing}

McLoughlin's

Trust Model

260

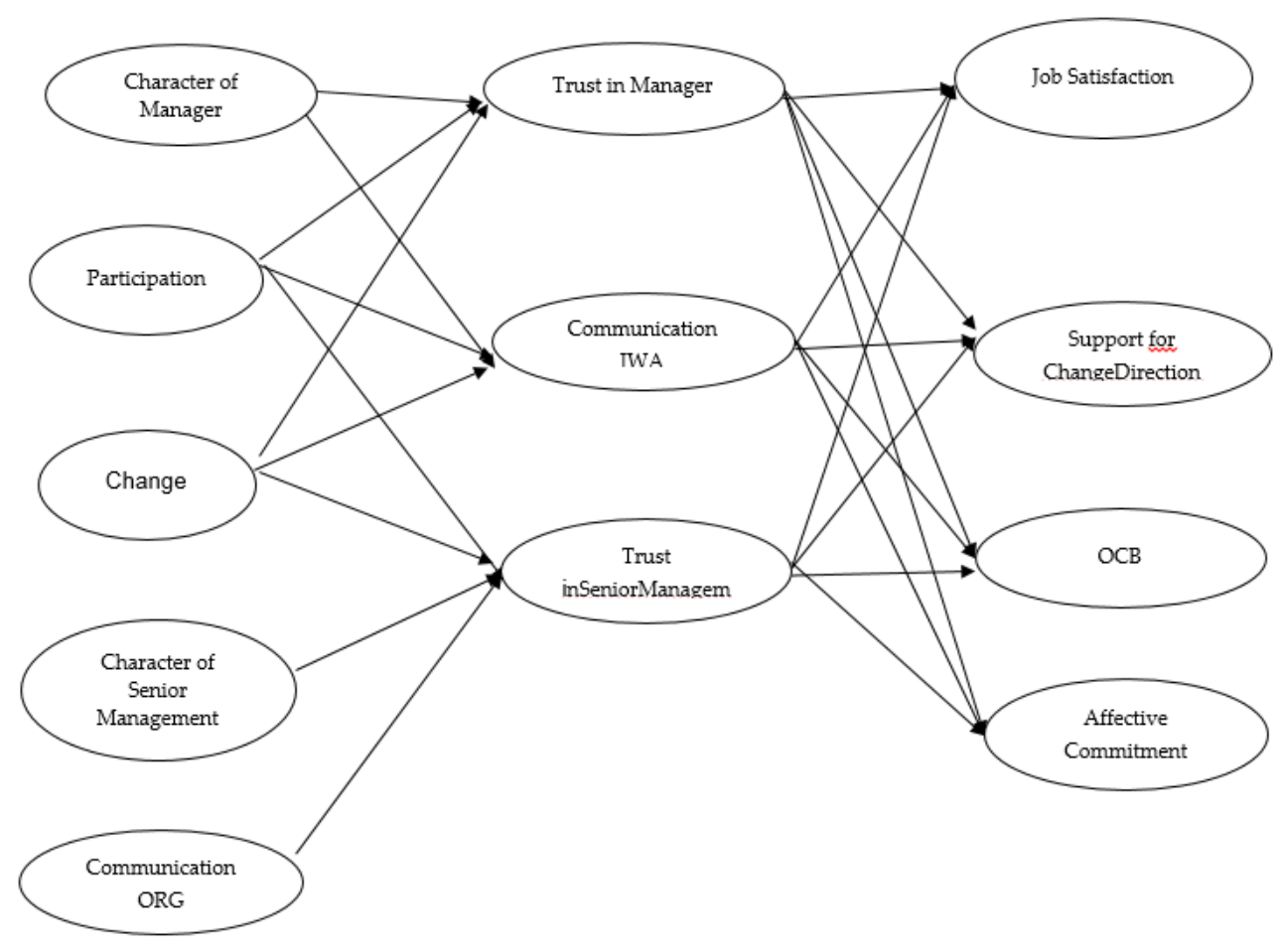

Figure 1: Initial Statistical Model in PLS (based on the Australian maximised model)

As it is seen in figure 1 McLoughlin's (2014) Model includes;

Effects of character of managers on trust in senior managers, management and communication; It is important to note that personality has been widely studied in terms of organizational psychology and empirical findings supports that the perceived personality traits of supervisor could have both positive or positive effects (Volmer et al., 2016) on employees work attitudes.

The model analyses the role of participation in organizational process especially in decision making. Since neo-classical management approach, integrating employees in decision making have been found a necessary and effective management practices.

Change is a key concept in today's information age, although it provides some important possible advantages to the organizations, it may not always be a preferable issue in terms of employees. Considering the IT organizations or knowledge employees, change is indispensable. However little is known whether change is perceived a positive or negative issue. Therefore examining the effects of change on trust and employee attitudes is 
expected to provide more insight on the role of change in terms of organization.

Communication is considered a vital issue in terms of knowledge sharing and coordination inside an organization. Specifically for IT companies, communication is significant. Because all information and knowledge must be shared to the necessary employees and units in IT companies.

On the other hand it is important to examine how trust in management and managers and also communication effects critical employee attitudes such as commitment, satisfaction and organizational citizenship behaviour. Also examining the mediating effects of trust in management, trust in managers and communication on employee attitudes will provide better understanding of trust in organizations. Thus McLoughlin's (2014) model includes significant variables in one single model. However it is not clear whether this model is coherent with other cultures or not. Therefore we aimed to test his model in a more collectivist culture just to test if this model produces similar results or not. The existing theoretical model of the key circumstances of trust within knowledge-based workplaces is explained briefly. In this study, by using a series of questions2 from research based in McLoughlin's (2014) study on Australian IT organisations, we replicated McLoughlin's (2014) research in the Turkish IT industry.

\section{II.Method}

This section begins by describing the target population and level of analysis. The survey method and limitations are discussed. The data gathering is outlined and the analytical procedures.

\subsection{The Target Population}

The target population was identified by organisational function and occupation. That is workers in IT organisations (or functions) in Turkey. The decision was driven by the need to select knowledge work that meets Warhurst and Thompson's (2006:787) definition "The central characteristics of knowledge work are that it draws on a body of theoretical (specialized and abstract) knowledge that is utilized, under conditions of comparative autonomy...", as well as displaying high levels of change. To ensure that the sample population approximated the definitional features, organisations and departments with high degrees of work autonomy and knowledge were selected - such as software developers, software engineers and database

${ }^{2}$ In this article 'questions' are the items or measures used in the survey. 'Variables' are made up of single or multiple questions and reflect a concept drawn from the literature. 
Testing McLoughlin's Trust Model

262 administrators. Moreover, the IT industry, IT organisations and IT functions are strongly associated with theories of post-industrial society, information society, and more recently the knowledge-economy. IT organisations are also considered the archetypal knowledge-based workplaces, particularly those containing 'software developers' and 'software engineers' (Frenkel, et al, 1995).

\subsection{Level of Analysis}

Rousseau et al's (1998) definition of trust as a psychological state was adopted in the previous section. A theoretical model of the key circumstances of trust within knowledge-based workplaces was developed, based on an individual worker's trust in management. In addition, the definition led to trust being treated as an attitude for this research. These two factors determine the level of analysis as the individual worker. Because of the importance of identifying 'who trusts whom', and the possibility of influences on an individual's trust being affected by different layers of management within a workplace, trust in immediate manager and trust in senior management are dealt with separately.

\subsection{The Survey Method}

In attempting to draw a reasonable sample of IT workers, access to the workers would be needed. The survey method provides efficiency of time and resources, statistical validity and reliability and generalizability (Kan 2002), on the other hand surveys lack the capacity to capture the individual's complex point of view (Denzin and Lincoln, 2000), and rely on self-reporting, which may lead to fictitious or incorrect answers, and low response rates. The method may also lead to the 'illusion of precision' with a potential bias to the status quo, thereby acting as: "obstacles to paradigm shifts in our understanding..." (Conger and Toegel, 2002:176).

\subsection{Data Collection}

This research involved both online and paper pencil survey completion. In total 121 valid responses were obtained. Approximately $10 \%$ of the questionnaire forms were excluded due to missing data and poorly completed forms. Respondents were predominantly male (88 or $73 \%$ ) and a minority were supervisors ( 41 or $34 \%$ supervised the work of others). Most of the participants were employed by private sector organisations (112 or 93\%). This result is not unusual in Turkey because of the large number of small IT organisations.

\subsection{Analytical Procedure}

As this research explores the interrelation of the various circumstances affecting trust, the issues may be addressed using Partial Least Squares (PLS). As a component-based structural equation modelling 
technique, PLS offers several advantages over the better-known covariancebased SEM (CBSEM) methods. Where CBSEM relies on a maximum likelihood function to obtain parameter estimates for latent structural modelling, PLS focusses on the explanation of covariance across the model. Both CBSEM and PLS enable researchers to answer a set of interrelated research questions in a comprehensive model simultaneously (Gefen et al., 2000). The PLS technique however, offers a stronger explanatory rationale for multiple variables and a more nuanced understanding of possible pathways. This capability is particularly important in this dissertation, because the broader psychological trust research has established a number of different mechanisms through which trust may operate, and a number of other advantages, including use with small sample sizes (Chin, 2010).

\subsection{Measures}

As mentioned earlier, trust within knowledge-based workplaces has been assessed in Australia (McLoughlin, 2014, 2015). This study sought to replicate that research in a different language and culture, using the following variables:

Trust Reliance, Trust Disclosure, Trust in Organisation, Change, Perceived Character, Communication, Participation, OCB, Job Satisfaction, Support for Change Direction and Affective Commitment. As seen above, two demographic variables were included - gender and supervisor.

Therefore all the variables were measured by using the same items with McLoughlin's (2014) research. The items were translated into Turkish by Turkish authors and translated back into English. English translations were checked by the Australian researcher.

\subsection{Assessing the Questions}

Turning first to the 'validity' of the questions: The initial testing addresses discriminant validity, ensuring the questions are more strongly related to the variable they seek to capture, rather than any other question or variable. This testing is initially conducted by checking the cross loadings for all of the questions against all of the other questions (the monofactorial cross loadings). Each question loading on its own variable must be the highest number both across that row and down that column. A second test of discriminant validity is recommended using Fornell and Larcker's (1981) Average Variance Explained (AVE). The latent variables should be greater than the square of the correlations among the latent variables. Chin (2010) recommends that the AVE should also be higher than 0.5 for all questions, meaning that questions should account for at least $50 \%$ of the variance. 
Testing McLoughlin's Trust Model

Once the discriminant validity has met the benchmarks, the next test considers the internal consistency of the items within the variable using Cronbach's Alpha. The calculation of Cronbach's Alpha holds all of the paths from the questions to the variable as equal, although some questions may be stronger representatives of the variable than others. PLS accounts for this by giving each question a weighting that maximises the variance explained for the prediction of the variable. Therefore, a better measure of internal consistency in PLS is Composite Reliability which allows variable path weights (Chin, 2010). However, due to Cronbach's widespread use, and for comparability with other studies, both Cronbach's Alpha and Composite Reliability (Dillon-Goldstein's rho) are reported here. It should be noted that Composite Reliability will always be higher than Cronbach's Alpha and sometimes markedly so.3 Finally, the weighting in PLS also enables the retention of weaker questions because the weighting minimises those questions, or those questions can be removed. On balance, a superior internal 'reliability' can often be obtained in PLS by removing problematic questions.

The literature and the Australian research suggested an exploratory theoretical model for examining trust in knowledge-based workplaces. Due to the small sample size, the combined maximised model was tested. Participation and Change at both the immediate work area and organisational level were combined to form a single construct for each. Communication and Character were assessed using the two different referents of the immediate work area and the organisation. The various subcomponents of trust were combined to provide an overall assessment, and to allow the removal of questions from the construct. Because all of the testing mentioned so far is done in the context of a structural model, the theoretical model is specified as a statistical model in XLStat.4 The theoretical model is assumed until both discriminant validity and Composite Reliability have been established, although the poor questions relating to a variable may be removed. Only then does the testing of the statistical model itself commence. The model as specified is shown at Figure 1.

\subsection{Validity and Reliability of Variables}

\footnotetext{
${ }^{3}$ For example, if there are two questions that are very strongly related to the variable and a third this is very weak. In those circumstances Cronbach's Alpha will give each question an equal weighting of $33.3 \%$ to each relationship, whereas Composite Reliability will use a weighting based on strength of relationship, say $45 \%$ for the two strong measures, and $10 \%$ for the weak one.

${ }^{4}$ The analysis for this paper was done in XLStat, 2017, version 19.01.
} 
At this stage, the statistical model itself is not being tested; rather the discriminant validity and reliability of the variables are being assessed. Given the small sample size, weaker questions were eliminated and then reliability re-assessed. The questions which make up the variable Affective Commitment and Support for Change Direction (from the original study) did not meet the statistical criteria and so were removed.

Table 1 indicates that the variables that do meet the reliability criterion with D.G. rho above 0.7, with conventional Cronbach's Alpha comparison. Therefore, statistical support for the validity and reliability of the initial variables created for this research is established. Table 2 ( $a$ and $b$ ) reports on the Descriptive Statistics

Table 1

Composite Reliability and Cronbach's Alpha $\mathrm{n}=121$

\begin{tabular}{llll}
\hline \multicolumn{1}{c}{ Latent variable } & Dimensions & $\begin{array}{c}\text { Cronbach's } \\
\text { alpha }\end{array}$ & $\begin{array}{c}\text { D.G. rho } \\
\text { (PCA) }\end{array}$ \\
\hline Communication ORG & 2 & .55 & .82 \\
Character of Senior Management & 3 & .83 & .90 \\
Participation & 3 & .63 & .80 \\
Trust in Senior Management & 5 & .83 & .88 \\
Perceived Character IWA & 4 & .79 & .86 \\
Trust in Manager & 6 & .80 & .86 \\
Job Satisfaction & 3 & .73 & .85 \\
Affective Commitment & 3 & .72 & .84 \\
Change & 4 & .91 & .93 \\
Communication IWA & 3 & .60 & .79 \\
Support for Change Direction & 3 & .74 & .85 \\
OCB & 3 & .68 & .83 \\
\hline
\end{tabular}


Table 2(a).

Descriptive statistics

\begin{tabular}{llc}
\hline Construct & Code & Standardised Loading \\
\hline OCB & OCB2 & .81 \\
& OCB4 & .64 \\
\multirow{5}{*}{ Trust in Senior Manager } & OCB5 & .87 \\
& Trust Org B02 & .74 \\
& Trust_Org B03 & .75 \\
& Trust Org C02 & .76 \\
& Trust_Org C03 & .80 \\
& Trust_Org SN2 & .81 \\
Character of Manager & CHAR2 & .69 \\
& CHAR3 & .74 \\
& CHAR4 & .84 \\
Communication IWA & CHAR6 & .84 \\
& CMN1 & .82 \\
Trust in Manager & CMN2 & .87 \\
& CMN3 & .51 \\
& TrustD2 & .77 \\
& TrustD4 & .49 \\
& TrustD5 & .70 \\
& TrustR1 & .67 \\
& TrustR4 & .77 \\
\hline
\end{tabular}

Tablo 2(b).

Descriptive statistics

\begin{tabular}{ccc}
\hline Construct & Code & Standardised Loading \\
\hline \multirow{2}{*}{ Communication ORG } & CMN_ORG2 & .85 \\
& CMN_ORG3 & .81 \\
Character of Senior Management & CHAR_ORG2 & .80 \\
& CHAR_ORG3 & .91 \\
& CHAR_ORG4 & .88 \\
Participation & PAR_CHG1 & .80 \\
& PAR_CHG2R & .64 \\
Job Satisfaction & PAR_CHG_ORG1 & .82 \\
& JSAT2 & .81 \\
\multirow{5}{*}{ Affective Commitment } & JSAT3 & .82 \\
& JSAT4R & .77 \\
& AC1 & .77 \\
Support for Change Direction & AC2 & .83 \\
& AC3 & .79 \\
& SUP_CHG2 & .72 \\
& DIR_ORG1 & .87 \\
& SUP_CHG_ORG1 & .84 \\
& CHG_SPS1 & .87 \\
Change & CHG_EX1 & .83 \\
& CHG_SP_ORG1 & .93 \\
& CHG_EX_ORG1 & .91 \\
\hline
\end{tabular}




\section{III.Results}

From Figure 1, it can be seen that this research follows the Australian research. Trust is examined as trust in the immediate manager and trust in senior management. Comparison of the direct effects model, the partial mediation model, and the trust mediated model in that research completed the three steps recommended by Baron and Kenny (1986) to demonstrate mediation. Those tests revealed that the 'trust only' mediated model did not provide the best fit with the data. As expected, this research also meets the established benchmarks - the path coefficients, the mean communality, goodness of fit (GoF) and variance explained (R2).

The Australian research $(n=225)$ established a GoF of $0.940^{*}$ and the mean R2 of 0.493 . In this research, testing of relationships between the variables identifies the model which most robustly represents the Turkish data collected, as set out in Figure 2. It shows the highest GoF of $0.926^{*} 5$ and the mean R2 of 0.5436 . Table 3 provides the details of the values, with all of the values and paths significant at the 0.05 level (using bootstrapping). Chin (2010) recommends bootstrapping for testing significance. The number of resamplings recommended for confidence intervals is 1000 (Efron and Tibshirani, 1986). Confidence interval testing produces a lower and an upper bound (at the 95\% level for this research) and neither bound should contain zero for the benchmark to be achieved (Chin 2010).7

Interestingly this research also showed that change had a negative impact on communication in the immediate work area.

\footnotetext{
${ }^{5}$ Above the recommended standard of 0.90 and significant at the 0.05 level ${ }^{6}$ Higher than any other model, as is the mean Communality (AVE) at 0.557

${ }^{7}$ Bootstrapping randomly samples the data collected and fits it to the model. The procedure is akin to gathering additional sets of data and ensures that there is a level of consistency in the collected data, enabling a reduction in the probability that the relationships described in the model occur by chance. Hence the level of significance can be calculated.
}

\section{Testing \\ McLoughlin's Trust Model}


Figure 2: Relationships for Maximised Turkish Model

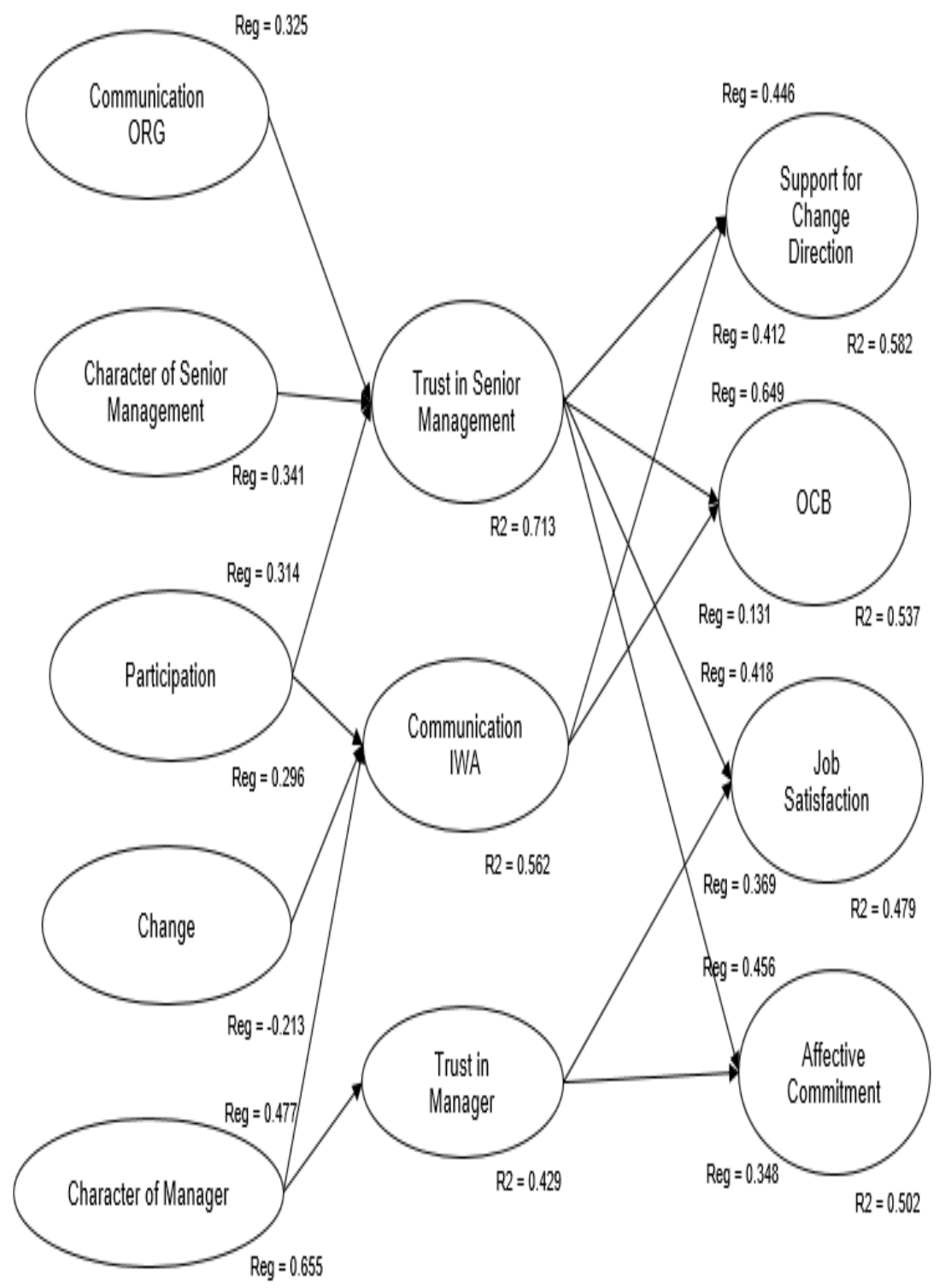


Table 3 (a).

Significance Testing, $\mathbf{R}^{2}$ and $p$ value for Maximised Mode

\begin{tabular}{|c|c|c|c|c|c|c|}
\hline Latent Variable & Value & $\begin{array}{l}\text { Value } \\
\text { (Bootstrap) }\end{array}$ & $\begin{array}{l}\text { Standard } \\
\text { error } \\
\text { (Bootstrap) }\end{array}$ & $\begin{array}{l}\text { Critical } \\
\text { Ratio } \\
\text { (CR) }\end{array}$ & $\begin{array}{l}\text { Lower } \\
\text { Bound } \\
(95 \%)\end{array}$ & $\begin{array}{l}\text { Upper } \\
\text { Bound } \\
(95 \%)\end{array}$ \\
\hline $\begin{array}{l}\text { Communication } \\
\text { ORG }\end{array}$ & .33 & .33 & .02 & 19.79 & .30 & .36 \\
\hline $\begin{array}{l}\text { Character of Senior } \\
\text { Management }\end{array}$ & .34 & .34 & .02 & 17.96 & .30 & .38 \\
\hline Participation & .31 & .32 & .02 & 18.91 & .28 & .35 \\
\hline $\begin{array}{l}\text { Character of } \\
\text { Manager }\end{array}$ & .66 & .67 & .08 & 8.48 & .50 & .79 \\
\hline $\begin{array}{l}\text { Trust in Senior } \\
\text { Management }\end{array}$ & .42 & .42 & .04 & 11.50 & .35 & .50 \\
\hline Trust in Manager & .37 & .38 & .04 & 8.61 & .29 & .45 \\
\hline $\begin{array}{l}\text { Trust in Senior } \\
\text { Management }\end{array}$ & .46 & .46 & .05 & 9.75 & .38 & .57 \\
\hline Trust in Manager & .35 & .35 & .04 & 8.07 & .26 & .43 \\
\hline Participation & .30 & .30 & .04 & 7.43 & .21 & .37 \\
\hline $\begin{array}{l}\text { Character of } \\
\text { Manager }\end{array}$ & .48 & .48 & .05 & 10.27 & .39 & .58 \\
\hline Change & -.21 & -.22 & .05 & -4.68 & -.30 & -.13 \\
\hline $\begin{array}{l}\text { Trust in Senior } \\
\text { Management }\end{array}$ & .45 & .45 & .04 & 12.82 & .38 & .52 \\
\hline $\begin{array}{l}\text { Communication } \\
\text { IWA }\end{array}$ & .41 & .42 & .03 & 12.94 & .35 & .47 \\
\hline $\begin{array}{l}\text { Trust in Senior } \\
\text { Management }\end{array}$ & .65 & .65 & .08 & 7.95 & .48 & .80 \\
\hline $\begin{array}{l}\text { Communication } \\
\text { IWA }\end{array}$ & .13 & .13 & .09 & 1.44 & -.05 & .30 \\
\hline
\end{tabular}

Table 3 (b).

Significance Testing, $\mathbf{R}^{2}$ and $p$ value for Maximised Mode

\begin{tabular}{lll}
\hline Dependent Variable & $\mathbf{R}^{2}$ & $\mathbf{p}$ \\
\hline Trust in Senior Management & .71 & 0.05 \\
Trust in manager & .43 & 0.05 \\
Job satisfaction & .48 & 0.05 \\
Affective Commintment & .50 & 0.05 \\
Communication IWA & .56 & 0.05 \\
Support for Change Direction & .58 & 0.05 \\
OCB & .54 & 0.05 \\
\hline
\end{tabular}


Testing McLoughlin's Trust Model

270
Table 3 ( $a$ and $b$ ) shows that the following antecedent associations are significant and positive at the .05 level. Participation, and character of manager are significantly associated with trust in manager and communication in the immediate work area. Participation, organisational communication and character of senior management are significantly associated with trust in senior management. As mentioned earlier change did have a negative and significant impact on communication in the immediate work area.

Table 3 ( $a$ and $b$ ) also shows that three mediators are significantly and positively associated with organisational outcomes. Communication in the immediate work area is associated with support for change direction and OCB. Trust in manager is associated with job satisfaction and affective commitment. Trust in senior management is associated with all four outcomes.

\section{IV.Conclusion}

In concluding this section on the data analysis, there are a number of important implications from the results. First, increased understanding of the antecedents, outcomes, and role of trust in the Turkish IT industry. Second, 'who trusts whom' does make a difference as the different operations of trust at different hierarchical levels within the organisation attest. Character of manager is a strong driver of trust for the immediate work area (and communication), perhaps because of the interpersonal dimensions of trust. Character of senior management and organisational communication are shown to be the strongest drivers of trust for the organisation. High levels of 'change', do have a negative effect on communication in the immediate work area. On the other hand it is important to state that the research has several limitations. It only includes a small number of sample size and the employees who participated to research were not purely from a big organization. Instead participations were chosen from several organization (i.e., small to big organizations).

The importance of participation in decision making for organisational trust has been highlighted. Communication is clearly important in the workplace, although analysis of the data suggests that communication in the immediate work area operates directly on organisational outcomes, while organisational communication has an impact through trust. Finally, the results from the data also support the importance of trust to organisational outcomes. 


\section{REFERENCES}

Beccerra, M. and Gupta, A.K. (1999). Trust within the organization: integrating the trust literature with agency theory and transaction costs economics, Public Administration Quarterly, 23(2): 177-203.

Börü, D., İslamoğlu, G. and Birsel, M. (2007).Güven: Bir Anket GeliştirmeÇalışması. Öneri. 7(27): 49- 59.

Chin W. W. (2010). Bootstrap Cross-Validation Indices For PLS Path Model Assessment. In V. E.Vinzi, W. W. Chin, J. Henseler\& H. Wang (Eds.), Handbook of Partial Least Squares Concepts, Methods and Applications, Berlin: Springer-Verlag, 83-97.

Conger A, and Toegel, G (2002). A Story of Missed Opportunities: Grounded Leadership Theory and Research. Information Sage Publication, Greenwich. 176-197.

Davis, J.H., Schoorman, F.D., Mayer, R.C. and Tan, H.H. (2000).The trusted general manager and business unit performance: empirical evidence of a competitive advantage", Strategic Management Journal, 21(5): 563-76.

Denzin, N. K., andLinkolnYvonna S. (2005). The SAGE Handbook of Qualitative Research. - 3rd edition. - London, New Delhi: Sage Publications,

Fornell, C., and Larcker, D.F., (1981). Evaluating structural equation models with unobservable variables and measurement error.Journal of Marketing Research, 18(1): 39-50.

Gefen D., Straub D., and Boudreau M. (2000). Structural Equation Modeling and Regression: Guidelines for Research Practice, Communications of the Association for Information Systems, 4(7): 1-70.

McLoughlin D. (2015).Knowledge Worker Trust Within Organisations. Ithikos Pty Ltd, Meyerson, D., Weick, K.E. and Roferick, M. (2006), "Swift trust and temporary groups", in Kramer, R.M. (Ed.), Organizational Trust, Oxford University Press, New York, NY, 415-44.

Moorman, C., Deshpande, R., and Zaltman, G. (1993).Factors Affecting Trust in Market Relationships.Journal of Marketing, 57: 81-1.

Özen, J. (2003). ÖrgüteDuyulanGüveninAnahtarUnsuruOlarakÖrgütselAdalet, in Erdem, F. (Ed.), SosyalBilimlerdeGüven, Ankara: VadiYayınları, 183-206.

Rousseau, D. M., S. B. Sitkin, et al. (1998). Not so different after all: A cross-discipline view of trust. Academy of Management Review 23(3): 393-405.

Shaw, R. B. (1997). Trust in Balance: Building Successful Organizations on Results, Integrity and Concern, San Francisco: Jossey Boss Publishers.

Straiter, K. L. (2005).The Effects of Supervisors Trust of Subordinates and Their Organization on Job Satisfaction and Organizational Commitment.International Journal of Leadership Studies, 1 (1): 86-101.

\section{Testing \\ McLoughlin's \\ Trust Model}


Testing

McLoughlin's

Trust Model

272
Volmer, J., Koch, I. K., andGöritz, A. S. (2016). The bright and dark sides of leaders' Dark Triadtraits: Effects on subordinates' career success and well-being. Personality and Individual Differences, 101, 413-418.

WarhurstC., and Thompson P. (2006). Mapping Knowledge in Work: Proxies or Practices? Work, Employment and Society, 20 (4): 787-800.

Webber, S.S. (2002). Leadership and trust facilitating cross-functional team success", Journal of Management Development, 21(3): 201-14. 